\title{
Traditional Neighborhood Adaptive Reuse in the Old City Sana'a, Yemen
}

\author{
Laila Ahmed Haidar ${ }^{1}$, Anuar Talib² \\ ${ }^{1} \mathrm{PhD}$. Candidate, Faculty of Architecture, Planning and Surveying, \\ ${ }^{2}$ Associate Professor Dr., Faculty of Architecture, Planning and Surveying, \\ Universiti Teknologi MARA UiTM, Shah Alam, 40450, Malaysia \\ haider.laila@gmail.com, anuarfaqir@gmail.com
}

\begin{abstract}
The study aims to identify the current conditions of the traditional neighbourhood (Hara) environment of Sana'a old city and to evaluate the outcomes of adaptive reuse. A case study of Hara Al-Abhar was made with the following instruments: On-site spatial observation and measurements and in-depth structured interviews. The study revealed the enhancement of income to house owners and the revival of traditional handicrafts. The disadvantage is that it disturbs the resident's privacy with the increment of vehicular accessibility and previously open public spaces and streets becoming parking spaces. This led the womenfolk to retreat into their houses.
\end{abstract}

Keywords: Adaptive Reuse, Traditional Neighborhood, Old City, Sana'a-Yemen

eISSN 2514-751X @ 2018 . The Authors. Published for AMER ABRA cE-Bs by e-International Publishing House, Ltd., UK. This is an open-access article under the CC BY-NC-ND license (http://creativecommons.org/licenses/bync-nd/4.0/). Peer-review under responsibility of AMER (Association of Malaysian Environment-Behaviour Researchers), ABRA (Association of Behavioural Researchers on Asians) and $c E-B s$ (Centre for EnvironmentBehaviour Studies), Faculty of Architecture, Planning \& Surveying, Universiti Teknologi MARA, Malaysia DOI: https://doi.org/10.21834/aje-bs.v3i10.326 


\subsection{Introduction}

The traditional quarters in the old city of Sana'a planned and built to fulfill the resident's essential needs of life such as safety and security, water resources, agriculture, health, education, culture and religion. The quarter component creates a friendly and neighboring environment. The social bonding is very strong among the residents because of their daily or weekly private and public gatherings for religious, social and cultural events.

The adaptive reuse as a practice in Sana'a Old City started with the onset of economic crisis in Yemen in the 1990's led most of the owners to find an alternative source of income by renting their ground floor for shops, hence known as shop houses. The choice of the new function is up to the owner. A legal planning permission should be obtained from the local authority. Being a UNESCO heritage site, the authorities must exercise a degree of control and regulations on the popular trend on building adaptive reuse.

The study has two objectives: 1) To identify the adaptive reuse current conditions of the neighborhood components and 2) To evaluate the advantages and disadvantages of adaptive reuse on the social-economic and cultural aspects of the traditional neighborhood built environment.

\subsection{Literature Review}

The adaptive reuse is an approach of changing the building function when the original purpose of the building is no longer viable (Douglas, 2002). It is an approach that raises funds. The private investors and nongovernmental institutions allowed the historic facilities for commercially viable ventures that respect their historical value and to earn profit from the use. The change of use, it may cause loss of the heritage authenticity in the historic city. The original character of the city could be lost along with the intangible heritage of habitat social activities and practices. The English Heritage (2000) the main idea of what represent reuse and the importance related to the heritage appear to be almost eventual than ever.

\subsection{The Practice of Adaptive Reuse In Yemen}

The international conservation of the Old city Sana'a by UNESCO had led the Yemeni government to initiate the General Organization for the Preservation of The Old Sana'a in 1984. Its main assignment was to study the historical background and the house's description of the old city of Sana'a. From 1987, the scope extended to include all the historical cities of Yemen.

The conservation of the old city Sana'a took place by the GOPHCY with the assistance of UNESCO and UNDP collaborating with private sectors, hotels and privately owned houses of architectural significance. The beginning of adaptive reuse movement took place by international organizations that collaborated with the local authority, to encourage the traditional handicrafts. Example the renovation project of the Caravanserai (Samsara) AlMansorah into a crafts shop and Al-Mutahar house into a Women Technical Center (Petzet \&Koenigs, 1995).

The adaptive reuse projects have spread all over the old city by private owners with no consideration for refurbishing or adapting them according to regulations and into a suitable 
usage. A lot of random renovations of traditional buildings and installation of new services took place (UNESCO, 2008).

\subsection{The Traditional Neighborhood in the Old City of Sana'a}

The Old City of Sana'a composed of two main areas which are the commercial and residential. The commercial area is a road of shop houses branching into markets (Souq). It commences from the main gate Bab El-Yemen and extends to the other end of the city gate Bab-Shuob. The residential area is divided into three zones, directed from the west to east namely: (1) Al-Kateh near the Palace of Weapon, (2)Al-Surar East located on the west side of the city center market (Souq), (3)Al-Surar West located on the west side of the rain drainage tunnel (Sailah) which ends at Abdul Mogni street. Each zone will differ in the number of quarters refer to Figure1.

The traditional quarter (Hara) is the main component of the urban formation. There are around 61 quarters in the old city of Sana'a. The biggest are Bustan Al-Sultan, Al-Fulayhy, Al-Elmy, Al-Madrasah and Al-Tabri. The smallest are Muteer, Zabarah, Al-Maftoon and AlHasosah (Al-Taher, 2005). The quarter's names are selected from to the oldest mosque within it, or sometimes to the family name of the famous resident based upon his status in the society or his distinguished house in the concerned quarter.

The prototype of a quarter component will consist of the following; (a) Housing Unit, (b) Mosque, (c) Open Space (Surha) (d) Water Fountain(Al-Sabil), (e) Fruit and vegetable Garden (Megshamah) (f) and hot bath (Hamam) as shown in Figure 2. Inhabitants of other quarters may share the buildings of public services even though they do not belong to that neighborhood. These interactions among the city inhabitants created social bonding and help eradicate the societal classifications and the tribalism by the process of integration.

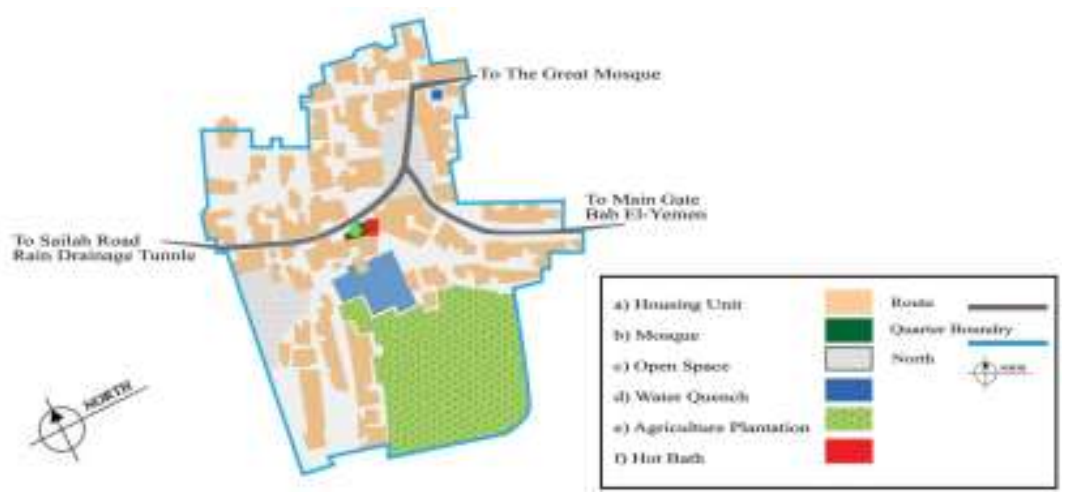

\subsubsection{The Housing Unit}

Fig 2. The prototype of quarter component

The traditional tower houses built in the old city of Sana'a are multistory that may rise above 5 floors. The house spatial organization designed in a vertical axis, normally the ground floor for animal and storage (Lewcock R., 1986). A number of tower houses forms the housing unit 
within a quarter. Each tower houses varies in the space layout and the floors number that reflects the owner's occupation hierarchy in the society. The house spatial layout can be divided into three categories (See Table 1) depending on the owner's social status in society as follow:

(1) Small sized house space layout ranges between 35 to 70 sq.metres, Consisting of 2 to 3 floors belonging to the lower class workers and servants, while farmers has houses ranging from 4 to 6 floors.

(2)Medium sized house space layout: it ranges between 150 to 250 sq. metres consisting of 4 to 7 floors belonging to the middle class society like craftsmen and traders.

(3) Large sized houses and sometimes cluster of tower houses surrounded by courtyard space layout ranging between 600 to 1000 sq. metres consisting of 6 to 8 floors belonging to high class families who works as best merchants, governors and judges.

Table 1. The Tower House classification According To The Occupation Hierarchy

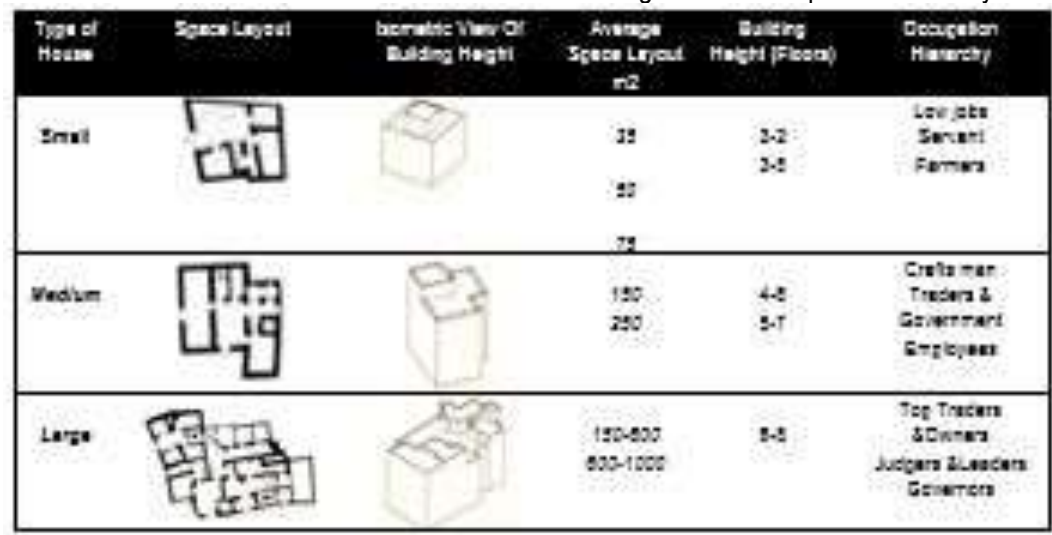

Source: adopted from Al-Taher, (2005)

\subsubsection{The Mosque}

The mosque location based on two factors; firstly of easy access and connectivity with other spaces to be practical for people, secondly the land ownership is public or under "wakaf" (endowment) control. It plays important role in the Yemeni society commencing with cultural event of marriage and death to some cases of serious issues are settled in the mosque either of an individual or as community, instead of going to the court, as the mosque being Holy and earned an exceptional respect from people is considerable. Also accommodates travelers or others in need of food or clothes sponsored by the members of the local mosques.

\subsubsection{The Open Space (Surha)}

The open space is a gathering point for the residents of various social classifications and the travelers. . Children use these spaces as playgrounds. The open space varies in size; normally the biggest will be near the mosque. Their numbers and locations will depend on the quarter size and orientation. This space creates social interaction of cultural activities 
such as marriage and death. Overall it enhances the urban connectivity of places and social interactions, to sustain the Yemeni culture to care for and help each other.

\subsubsection{The Water Fountain (Sabil)}

The place for quenching the thirst for travelers and strangers, some spaces will have extra pool for animals and birds. The architectural expression of the Sabil dome and ornaments and is an essential component of the Islamic city, related to the mosques, the open spaces (Al-Surha) and the main pedestrian routes.

\subsubsection{The Fruit and Vegetable Gardens (Megshamah)}

One of the central urban components of the quarter, It connects the mosque and designed to surround the houses for better views. This garden space used the waste ablution water from the mosque for the plants before city sewage system installation.

\subsubsection{The (Hamam) Hot Bath}

It usually built next to the mosque to share water and easy access for both male and female inhabitants of the quarter. It serves as a social and cultural space, for instance as a wedding function for women with Henna bodily decorations prior to the wedding day.

The connection among the quarter components creates a social environment among the habitat; the changes that accrued with the new function had affected the social environment and some of the quarter component of an original function. The research findings will elaborate on the current condition of the quarter components and their effects on the social environment.

\subsection{Methodology}

The case study of Hara Al-Abhar Quarter is one of the traditional neighborhoods in the old city of Sana'a, located in the south of East Al-Surar Zone on one of the roads to the main gate of Bab El-Yemen, Al-Qasmi to Al-Sailah and the Great Mosque as shown in Figure 3. The total area is 24813 meter sq. estimated to occupy the $1.8 \%$ of the whole city space with 358 inhabitants. The tower houses composed of $44 \%$, the Open Space (Al-Suhra) at around $13.5 \%$, the Hot bath (Hamam) at $0.4 \%$, and the religious buildings (Mosques and Madrasah) at $6.0 \%$. This quarter has a few open spaces of different sizes that connect to the neighborhood roads and paths, estimated to occupy a space of $22.1 \%$ of the whole quarter.

The data collection commence with site survey, to record the buildings original function and the adaptations type. The purpose is to investigate the relation of new functions with the original social attributes and activities. The survey duration was for one month. The second stage of data collection uses in-depth structured interviews with the Local Building Authority, site inspectors and architects in order to investigate the building permission procedures and requirements. A number of interviews made with the house owners, to ascertain if they had 


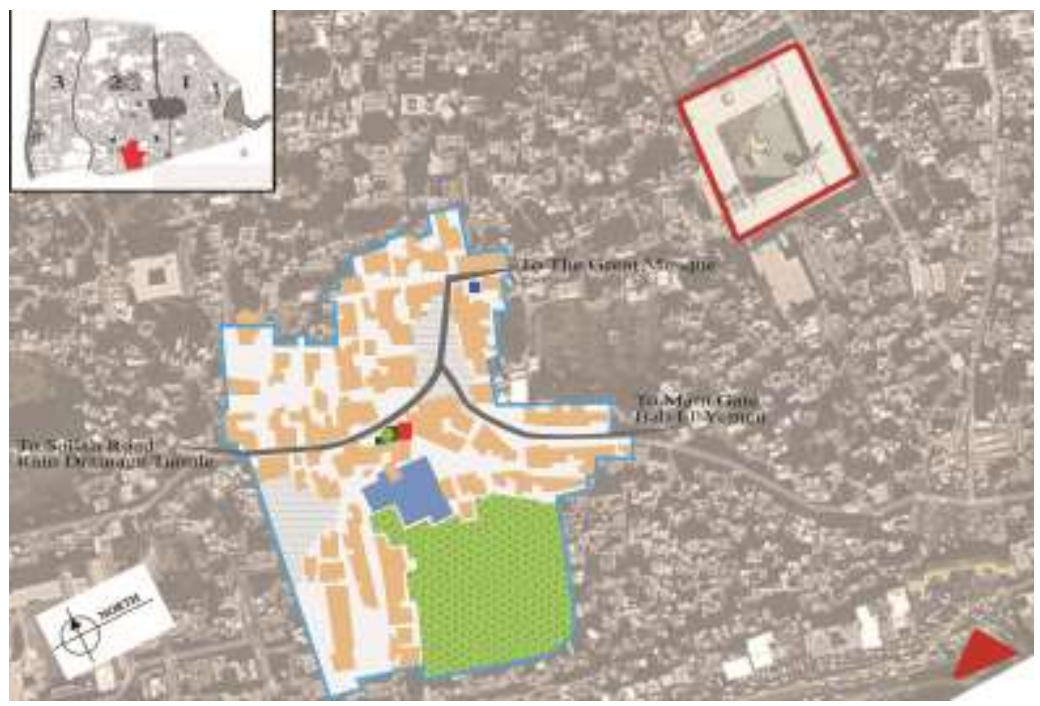

Fig 3. The Component And Boundary in Al-Abhar Quarter

obtained building permission (CHUA \& DEGUCHI, 2011). Also to understand if they accept the new changes.

The Scaled Drawings and building measurements are obtained from the Conservation Institution (CATS) and the Local Planning Authority as an essential part of the research data which provide valuable insight into the building's original planning and any significant changes which may have resulted from the adaptive reuse.

\subsection{Results and Discussions}

\subsection{The Current Changes Of The Traditional Quarter Components}

The residential tower houses have changed into commercial purpose through adaptive reuse. There are two types of projects categorized as follow; One, is a government project and fund and in most of the projects will collaborate with an international organization, for experts and fund normally the selected houses will be of historical significance. Two, is a local private ownership where the owner is the only source of; funding the project, decision making on the choice of function and the degree of building intervention. This category is most prevalent and lacks control by the authority.

There are two types of house building adaptation; firstly a total adaptation for all the floors of the house, and secondly a partial change for the ground floor at street level only (Refer to Figure 4). 


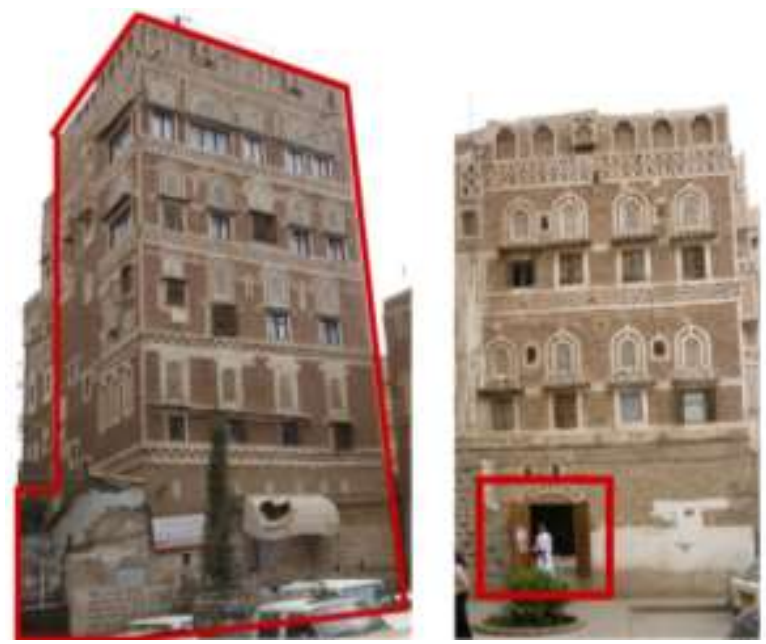

Fig 4. Indication Of The Space Of Adaptation On The Tower House, Left Side Fully Adaptation, Right Partially

The first type found on the site survey of 5 samples 3 samples are traditional house adapted into the following functions: (1) The cultural Yemeni house funded by the General Organization for the Preservation of the historical cities in Yemen (GOPHCY) (2) Sana'a Hotel private ownership (3) Girls School That-Alnetakaeen, the other 2 samples of new building style as a charity organization.

The second type is partial whereby the ground floor of the house traditionally used for keeping animals, now days opened to the road which may be rented out or as a mean of alternative source income. They are located on the main road with heavy pedestrian traffic offering a variety of shops; grocery, sandwich shops, wedding services, hairdressers and mobile services. It spreads from the open space, and the number increases towards the main gate on both sides of the road, see Table (2).

Table 2. Type of Adaptation, project and Functions

\begin{tabular}{|c|c|c|c|c|}
\hline $\begin{array}{l}\text { Type of } \\
\text { Adaptation }\end{array}$ & Type of project & Type of function & Signifcance & $\begin{array}{c}\text { Number } \\
\text { of } \\
\text { Samples }\end{array}$ \\
\hline \multirow[t]{2}{*}{ Fully } & $\begin{array}{c}\text { Governmental Local } \\
\text { authority } \\
\text { Collaboration with } \\
\text { international } \\
\text { organization }\end{array}$ & $\begin{array}{l}\text { Cultural Yemeni house } \\
\text { Girls School } \\
\text { Charity Organization }\end{array}$ & $\begin{array}{c}\text { Cultural } \\
\text { Educational } \\
\text { Social \&Economics }\end{array}$ & 4 \\
\hline & Private ownership & Hotel & Economical & 1 \\
\hline Partially & Private ownership & $\begin{array}{l}\text { Grocery- Sandwich- } \\
\text { Weeding services- Hair } \\
\text { dresser for ladies- } \\
\text { Storage. }\end{array}$ & Economical & 25 \\
\hline
\end{tabular}


The direct change of function is clear on the residential houses for the other quarter components is indirectly affected by introducing the new functions into the quarter that created less privacy within the neighborhood to become less utilized and services.

\subsection{The Advantages And Disadvantages Of Adaptive Reuse On The Social Aspect Of The Traditional Neighborhood Built Environment.}

The traditional neighborhood planned on a closely-knit functional spaces which preserves the individual privacy, based on the Islamic teaching and Yemeni culture promote social integration among the inhabitants within an open space built environment. This traditional code replaced by the Building Bye Laws that administered by the modern legal system which may not be compatible.

Table3. Comparison Between The Traditional And Current Function And Social Effects.

\begin{tabular}{|c|c|c|c|c|}
\hline \multirow[b]{2}{*}{ components } & \multicolumn{2}{|c|}{ Social activities } & \multicolumn{2}{|c|}{ Adaptive reuse affect } \\
\hline & Traditional activities & Current use & Advantages & Disadvantages \\
\hline $\begin{array}{c}\text { Tower } \\
\text { Houses }\end{array}$ & $\begin{array}{l}\text { Residence Social } \\
\text { gathering animals } \\
\text { storage at ground level }\end{array}$ & $\begin{array}{l}\text { Ground floor } \\
\text { opening road } \\
\text { shop - or adapt } \\
\text { the whole } \\
\text { building }\end{array}$ & $\begin{array}{l}\text { - Commercial shops } \\
\text { instead of walking } \\
\text { to the market area. } \\
\text { - Alternative income } \\
\text { for the owners } \\
\text { - Depend on the } \\
\text { visitors shopping. }\end{array}$ & $\begin{array}{l}\text { - Lack of family privacy with } \\
\text { the accessibility of } \\
\text { strangers/visitors and } \\
\text { vehicles into the residential } \\
\text { quarter. } \\
\text { - Social places are not used } \\
\text { cause of lack of privacy } \\
\text { - to gather around the } \\
\text { drinking water pools and } \\
\text { the plantation garden }\end{array}$ \\
\hline Open Spaces & $\begin{array}{l}\text { Gathering point of the } \\
\text { quarter- social talk and } \\
\text { solve issues - kids play } \\
\text { ground }\end{array}$ & Parking lot & $\begin{array}{l}\text { Parking space close to } \\
\text { the house and market } \\
\text { for visitor }\end{array}$ & $\begin{array}{l}\text { Accessibility of vehicles } \\
\text { disturbs the quarter } \\
\text { environment. not much of } \\
\begin{array}{l}\text { social gathering and kids } \\
\text { playing }\end{array}\end{array}$ \\
\hline $\begin{array}{l}\text { Plantation } \\
\text { Garden }\end{array}$ & $\begin{array}{l}\text { Plantation garden for the } \\
\text { essential vegetables } \\
\text { use } \\
\text { Gathering place for } \\
\text { women folks and kids. }\end{array}$ & No plantation & & $\begin{array}{l}\text { lack of water supplement } \\
\text { abundant land } \\
\text { women lack outdoor space for } \\
\text { social gathering and } \\
\text { gardening }\end{array}$ \\
\hline Water Pool & $\begin{array}{l}\text { Water quench for } \\
\text { travelers, animals and } \\
\text { habitant }\end{array}$ & $\begin{array}{l}\text { lack of water } \\
\text { sources }\end{array}$ & $\begin{array}{l}\text { New water system } \\
\text { installed } \\
\text { Depend on the } \\
\text { government supply }\end{array}$ & $\begin{array}{l}\text { Lack of government supply } \\
\text { water collection from mosque } \\
\text { tank }\end{array}$ \\
\hline Hot Bath & $\begin{array}{l}\text { Public bath social } \\
\text { gathering especially for } \\
\text { marriage custom } \\
\text { sustainability of the built } \\
\text { environment dry dirt of } \\
\text { human excreta }\end{array}$ & $\begin{array}{l}\text { Still used but } \\
\text { with gasoline for } \\
\text { heating. }\end{array}$ & Service for residence & $\begin{array}{l}\text { Lack of sustainability in the } \\
\text { built environment }\end{array}$ \\
\hline
\end{tabular}


The adaptive reuse clearly introduced on the tower houses and brought environmental changes to the other quarter components. There are advantages and disadvantages that arise with the new building functions: affecting the social life and built environment of the inhabitants.

The data collection analyzed through a comparison of the quarter components social activities between the traditional and current situation, to understand the changes effects of advantages and disadvantages of the adaptive reuse, refer to Table (3).

The advantage on the socioeconomic life is that inhabitants receive new services such as nearby shops instead of walking to the traditional souk (market). Tower house owners make an additional income from shop rentals and tourist dollars on local traditional crafts.

This phenomenon had increased accessibility of strangers/visitors and motorized vehicles to services of the new shops and commercial ventures, claiming large areas from the open spaces as a parking space that disturbs the kids area with the cars passing by and people going to mosque and market but not many of social gathering this accessibility of vehicles disturbs the quarter environment.

The disadvantage rise with the lack of residence privacy within the residential quarter, women folks lose their privacy to gather around the drinking water pools and use of plantation garden space (Bustan) as a social gathering place.

Beside the reasons discussed previously plantation garden terminated cause of the lack of water supplement from the used ablution water of the mosque. Also, the water pool rarely used because the lack of water sources. The inhabitant depend on the government water supply that is in continues shortage, so womenfolk's and kids will depend on the closest source of mosque or water pool to fill in the tank and carry it back home.

A restoration program by a private developer attempted, but the people who take care of the land disagreed with the terms and conditions and more inclined towards selling the land, although land belongs to the authority but in the tribal concept that took care of it gets a share of it. Bureaucracy and corruption on the part of the Local Authorities stalled the proceedings. The sustainability in the built environment by the previous method of heating the hot bath creates from dry dirt of human excreta to gasoline.

\subsection{Conclusion}

From this research, found that the traditional quarter components effectively changed with the adaptive reuse of the tower houses. This had affected the physical building and impacted on the traditional social fabric by encroaching on the residences privacy primarily on women's accessibility due to the increased activity at shops on the ground floor. As the traditional components of the quarter related closely to the residence way of living, The present dwindling functionality of particular components that no longer be used as before; therefore, it had infringed on the social aspects of the traditional quarter and the old city as a whole. The study recommends conserving the traditional quarter, by controlling the number of shop houses within the residential quarter with a variety of services that will control the repetition 
of business. Also, to limit the vehicles accessibility to the open spaces and roads for residence of the quarter only. The Government and private organization should organize the fund for the houses restoration program and control of adaptation type and function. Enhance the public awareness on the houses restoration and intervention.

\section{Acknowledgement}

The author wishes to thank several people, I would like to thank Associate Professor Dr. Anuar Talib for his assistance and guidance with this paper, all experts from local authority for their patience with the interviews, and the quarter inhabitants for their kindness, honesty and help. Finally I would like to thank my parents, siblings and friends for their lovely support.

\section{References}

Chua, R. S., \& Deguchi, A. (2011). Tourist Dependent Adaptive reuse in the old residential quarter of Melaka city. Malayisa. J.Archit. Plann.

Cooper, I. (2001), “Post-occupancy evaluation-where are you?”, Building Research \& Information, Vol. 29 No. 2, pp. $158-63$.

Douglas, J. (2002). Building Adaptation. Butterworth Heinemann.

GOPHCY. (1988). Women't Technical. Sana'a: General Organization for the Protection of the Historic Cities of Yemen.

ICOMOS, A. (1999). The BURRA CHARTER. Australia: Australia ICOMOS.

Lamprakos, M. (2005). Rethinking Cultural Heritage: Lessons From Sana'a, Yemen. TDSR.

Langston, C., \& Shen, L.-Y. (2007). Application of the adaptive reuse potential model in Hong Kong:A case study of Lui Seng Chun. nternational Journal of Strategic Property Management , 193-207.

Lewcock, R. (1986). The Walled City of Sana'a. UNESCO.

Lowe, R.J. (2004), "Lessons from climate change: a response to the commentaries", Building Research \& Information, Vol. 32 No. 1, pp. 75-8.

Organization of Islamic Capitals and Cities. (2005). An analytical study on the capital Sanaa. In The foundations of architectural design and urban planning in the various Islamic eras.

Petzet , M., \& Koenigs, W. (1995). The Restoration of the Samasarat-al-Mansurah. Munchen.

Rodwell, D. (2007). Conservation and Sustainability in Historic Cities. UK: Blackwell.Samson, P. (1995). The Concept of Sustainable Development.

Serageldin, I. (1982). Rural Architecture In The Yemen Arab Republic: The Impact of Rapid Economic Growth on Traditional Expression. 
Ahmed Haidar, L., \& Talib, A. / Asian Journal of Environment-Behaviour Studies (ajE-Bs), 3(10) Sep / Oct 2018 (p.187-197)

UNESCO. $(2008,1216)$. The Inventory of the historic city of Sana'a: a tool for urban conservation. Retrieved MARCH 29, 2012, from UNESCO: http://whc.unesco.org/en/activities/569/ 